\title{
Bodily Entanglements: Gender, Archaeological Sciences and the More-than-ness of Archaeological Bodies
}

\author{
Christina Fredengren
}

\begin{abstract}
Critical feminist Posthumanism provides novel ways of dealing with bodies as materialdiscursive phenomena. As such, bodies come about, change and dissolve by re-workings of entangled relations. Such relationships are making human bodies more-than-human. Bodies can be understood as full of excesses - that will not be captured by, for example, gender or age categories alone-albeit occasionally materially shaped by them. Examples of such excessive relations are captured by DNA analysis or various isotope analyses-where diet as well as geological habitat gets imprinted into the body and become a part of the personhood-and can be discussed as the landscape within. This paper deals with some misunderstandings around Posthumanism, but also with how critical posthumanist feminist theory can breathe new life into archaeological gender studies and thereby also forge new relationships with the archaeological sciences.
\end{abstract}

\section{Critical Posthumanism and gender in archaeology}

Marie-Louise Stig Sørensen (2013) has described gender archaeology in Scandinavia making use of the terms first-, second- and third-wave feminism. Feminism is often periodized in this way (see van der Tuin 2014), and first-wave feminism dealt with the gaining of gender equality in the workplace. The second wave is often connected to questions of sexuality, family and reproductive rights. Furthermore, it includes the questioning of epistemologies and classifications where, for example, biological sex was distinguished from socially constructed gender. In archaeology, the third wave came with the postprocessual archaeologies and the development of more theoretical agendas that engaged with questions of how gender is inscribed onto material bodies (Engelstad 2007; Sørensen 2013). This wave has also been connected to questions around power and how the intersectionality of overlapping identity categories coincides in and forms oppressive structures. Here, importantly, Sofaer $(2006 ; 2013)$ has made use of performative gender theories such as those of Butler (1990; 1993) to bring change to osteological studies.
What I would like to add to feminist gender studies in archaeology, drawing on van der Tuin $(2014,16)$, is that there are more routes to explore in order to expand the field of gender studies in archaeology. This paper provides an encounter with critical feminist Posthumanism and New Materialism that does not adhere to any of these waves and runs eclectically straight through them.

The focus in this paper is to trace how these approaches work well in a meeting with the archaeological sciences (in dealings with, for example DNA, isotope analysis or osteology), as they open up possibilities for work in what could be called a post-postmodernist stance that allows for tracing discursivities coupled with a range of sources and forces that work within and through our bodies. Thereby critical posthumanism can boost gender archaeology too, in ways that both give the opportunity to reflect on the natural sciences and provide new ways of posing questions, but also in methods and results that recognize bodies as more-than-human power nexuses, that need to be recognized as important agencies for understanding historical processes of stability and change.

Cambridge Archaeological Journal 31:3, 525-531 @ The Author(s), 2021. Published by Cambridge University Press on behalf of the McDonald Institute for Archaeological Research. This is an Open Access article, distributed under the terms of the Creative Commons Attribution-NonCommercial-NoDerivatives licence (http://creativecommons.org/licenses/by-nc-nd/4.0/), which permits non-commercial re-use, distribution, and reproduction in any medium, provided the original work is unaltered and is properly cited. The written permission of Cambridge University Press must be obtained for commercial reuse or in order to create a derivative work.

doi:10.1017/S0959774321000226 Received 21 Jan 2020; Accepted 4 Feb 2021; Revised 15 Dec 2020 
However, in order to do this, I will first deal with some misapprehensions around feminist Posthumanisms and their links to power and gender. Secondly, I will outline how these theories can be useful for linking the archaeological sciences to gender writings in new ways, drawing on Barad (2007), Braidotti (2013) and Alaimo (2010). Thirdly, I will refer to a few examples to highlight how their framework may allow us to see other aspects of archaeological material and the processes that make it come about. Finally, I will try to articulate what critical posthumanist feminism does and could do for gender archaeology, by referring back to this introduction. Here, I am to some extent making use of arguments in earlier papers (Fredengren 2013; 2018a,b) as well as Harris' (2020) research on related topics. However, I am placing these ideas in a history of ideas of gender studies in archaeology-and it will be argued that there is a need to heed the more-thanness of variously situated archaeological bodies and to proceed with gender research that engages more critically and affirmatively with the natural sciences than is the way in current archaeology.

\section{Posthumanism and power analysis}

Questions have been raised with regard to Posthumanism and the disregard of its theories for power and gender analyses. González-Ruibal (2018, 12) has written that the very necessary vindication of things has meant that all-too human relations of power and conflict have virtually disappeared from our accounts' and worries that the posthuman approaches shy away from power analyses. Intriguingly, Gonzalez-Ruibal exemplifies the posthumanist philosophy underpinnings with reference to an outspoken feminist scholar, Rosi Braidotti, to whom power analysis is central. However, there are many variants of Posthumanism. Those labelled as Object Oriented Ontologies have been trending in archaeology and heritage studies and favourably adding ways of how to deal with things more symmetrically (see Witmore 2015); power analysis may not have been their main focus. Differently from such posthumanisms, the work of, for example, Braidotti (2013) and Barad (2007) provides tools to analyse the world's becoming through relational and material-discursive changes that highlight the development of power differentials and gender matters.

However, at the same time as various forms of Posthumanism have started to influence archaeology, some of the archaeological interpretations making use of these theoreticians have underarticulated their origin in feminism. This is exemplified in the work of Fowler (2013) that analyses Bronze Age mortuary practice, which, while making use of Barad to form a relational realist approach, does not engage particularly deeply with feminism and gender studies. Also, when posthumanist approaches start to appear in introductory work of archaeology, such Harris \& Cipolla (2017), the contribution from feminist critical theory needs a firmer grounding. Taken together, these factors might have contributed to the view that Posthumanism does not engage in matters of power, nor have a great potential for bringing gender archaeology into new fields of archaeology (but see the writings of Fredengren 2013; 2017; Hjørungdal 2012; Marshall \& Alberti 2014). Here Hjørungdal (2012) writes that Barad's works are useful for querying the links between nature, culture and science in archaeology. I would like to take these thoughts further and emphasize how critical feminist Posthumanism provides tools for engaging in gender archaeology in new ways. What critical feminist Posthumanism problematizes is the strange history and complexity of 'humanity' as a category often used to elevate certain individuals over others, to create a 'pure' species category, that of the human species, which also appeals to the idealized figure of ' $m a n$ '. Such a figure remains exclusive for a selected group of people and works to de-humanize a range of othered others. The ringfencing of such normative humanity has often neglected writing the history of a range of naturalized others, as has been pointed out in LGBTQI+ and postcolonial studies. Such questioning approaches have entered academia through seminal work such as, for example, Material Feminism, New Materialism and Posthumanism (see Alaimo 2010; Barad 2007; Braidotti 2013) that traces out materializing nexuses of power emerging through bodily entanglements. It is also evident in ongoing questioning and unsettling the normalizing work of binaries such as man/woman, culture/nature, human/animal or life/death.

\section{Critical Posthumanism and body theory}

So, the question is how these posthumanist theories, in their feminist take, can be useful for linking the archaeological sciences to gender writings in more powerful ways. Here, scholars such as Barad (2007) and Braidotti (2013) have taken a great interest in the interface between humanities and natural sciences. These insights can be used for the production and writing of more inclusive histories that consider how bodies matter, beyond how they are represented by identity categories alone. Bodies can 
be approached as processes that come about and undergo change when they enter into new relations. Scientific measurements are stark meeting-points of the natural and the social and, according to Barad $(2007,67)$, in them meaning and matter meet to co-constitute each other. With this focus, posthumanist feminism works with how such measuring generates bodies and forms the subjectivities that matter. Furthermore, intersections of, for example, gender, class, ethnicity and also species as discursivities contribute to such formations. Important in this reasoning is that such discursivities have materializing effects.

However, discursive fields are not a privilege for humans only-material-discursive workings are also carried out by the more-than-human and where subjective bodies act back. This is a move that adds more agentialities to the Butlerian analysis than the logocentric ones, in ways that allow back into analysis the material forces that coincide in bodies. Discursive practices are '(re)configurings' (Barad 2007, 148) that emerge also through intra-actions, where subjects, entities and elements differentially and materially refract into and articulate the world - that is, these forces contribute to a worlding of bodies both through and disregarding anthropogenic speech acts. In short, bodies (for example the human and animal remains studied in archaeology) are brought into being due to mergers of both material agentiality and concepts, but they continue, once formatted and made, to come into place in particular situated bodily re-configurings and subjectivities.

Here Barad's agential realism provides methods that can be helpful for relating to the many natural sciences methods in archaeology, with implications for how bodily remains are approached and investigated. For Barad $(2007,128)$, the smallest analytical unit are phenomena, which are the 'specific intra-action of an "object"; and the "measuring agencies"; the object and the measuring agencies (apparatuses) emerge from, rather than precede, the intra-action that produces them'. What is of importance to bring home to scientific practices in archaeology is that the object that is researched entangles with the ways we examine it and, in that sense, there are no pure archaeological objects or no pure bodies to be studied, but only phenomena in the making. Barad $(2007,185)$ explains that 'knowing is a matter of part of the world making itself intelligible to another part. Practices of knowing and being are not isolable; they are mutually implicated'. Hence, scientific analyses of bodily remains can be understood as onto-epistemologies, where bodies are made intelligible by the efforts and apparatuses used to know them-they co-produce knowledge and existences of the phenomena in question.

Tim Sørensen $(2017,103-16)$ has problematized how natural sciences have been applied in archaeology, where one example is how both questions asked of the material as well as selection practices and statistics on occasion are scantily described. Furthermore, he argues, interpretations are levelled up to produce general truths for larger areas and periods, while sample sizes are generally too small for such broad claims-for example in the study of isotopes and metalwork (Sørensen 2017, 106). Another challenge with the methodological empiricism of natural science-based archaeological studies (Sørensen 2017) is that they work representationally, i.e. make claims to mediate the past as it was. What critical posthumanist feminism would alter in this argument is that the establishment of scientific facts, at the same time as it produces valid knowledge, needs to be understood as situated. A scientific measurement enrols apparatuses that make bodies intelligible and cause them to rise as phenomena and produce positioned enactments of bodily histories.

However, agential realism traces how the gelling together of material-discursivities cause diffractions, rather than exact mirrorings of the same. So, as van der Tuin (2014) also writes, science does not mirror nature, nor does social constructivism mirror and represent culture. Hence, laboratory results do not represent the past as it was, but give rise to phenomena that are brought about both through the agencies of observation and the materializing of historical bodily trajectories, where one does not fully match the other. However, this does not mean that history is created in a relativist way, but that archaeological methods bring into place particular situated space-time materializations as phenomena where both the slow sedimentation of matter and ways of observing produce and diffract historicity, rather than reflect history as it was.

Furthermore, critical posthumanist approaches are situated differently, for example, to how both second- and third-wave feminist theories approach sex and gender. Whereas second-wave gender archaeology may have made a case of distinguishing gender (the social) as separate from sex (the natural or biological), third-wave theories have made their way into archaeology. As mentioned above, Sofaer's (2006; 2013) contributions to osteology have probed into the gap between archaeological social constructivist approaches and osteology as a science, and engaged with Judith Butler's argument that biological sex is also socially constructed, down to the bone, so to speak. In that approach, gender is performed and 
acted out in the body $(1990,9-11,45-9)$ : this reasoning could be used in archaeology, too, in order to argue against separating sex from gender in osteological analyses. In such cases, for example, both osteology and DNA analysis would discursively impose categories onto the material through various performances that bring sex/gender into existence; however, this may render the osteological material mute. Critical feminist Posthumanism would acknowledge that gender is not something you have, but is made performatively, just as Butler argues, but add that a variety of materializing forces as well as agential cuts into an interconnected reality makes genderization come into play. The materialities of bodies, in conjunction with apparatuses of observation such as osteological nomenclatures, produce bodies marked up as, for example, human and male, or female. However, bodies are immersed in a number of relations, where such nomenclature highlights certain aspects and risks our turning a blind eye to other bodily entanglements.

\section{We are more than our bodies}

Some examples may highlight how a critical feminist posthumanist framework may allow for folding out new aspects of the archaeological materials and the processes around how histories come into being. One point of origin in these process-ontologies is that bodies come about through the development of several excessive relations. However, what this means needs a bit of thought and contrasting work. For example, the statement 'I am more than my body' could in archaeology be taken to mean, that such an ' $\mathrm{I}$ ' is added to and expanded and articulated by, say, clothing, jewellery or tasks that a human can use to build its subjectivity. However, in a Baradian $(2007,154)$ vein, the bodily remains studied in archaeology would be approached as having been produced by a number of different materializing forces of more-than-human origin. Furthermore, the imaginaries around the given-ness of body, or that personhood is crafted as an individual through human choice only, are under question. Instead of taking for granted the boundedness of the flesh, bodies are, as Alaimo (2010) points out, configured transcorporeally, where bodies are enmeshed and come about through interlinkages with the world, and as such co-produced by a number of more-than-human agencies, where for example both toxicities and systems of nurture are brought into play to format bodies. Furthermore, bodies are power nodes that come about through both repressive (potestas) and enabling/transformative forces (potentia), where
Braidotti $(2013,163-4)$ works with cartographies to trace how such situated subjectivities come about. In effect, bodies are not autonomous existences, but change through connectivities with others where power differentials affect which bodies prosper and which dwindle.

As discussed in my paper 'Becoming bog bodies' (Fredengren 2018b), a spatially situated sacrificial masculinity came about through the acting-out of a number of different power differentials where some of these bodies developed under malnutrition (which can be both humanly and non-humanly induced, through crop failure or unequal access to resources), the identification and selection of bodies singled out as mainly males, the possible exercise of de-humanizing and othering practices both in life and death, that worked together with the handling of bodies and depositions in wetlands and their slow processes of decay. This is an example of how power differentials might have been running along binary sorting of bodies into women and men, but also along lines of who had access to networks of care and who fell outside of such. However, the archaeological evidence for such sorting is only present in the wider study of watery depositions of human remains, in certain places and during particular time periods. In other situations, the gendered separation may have mattered less.

These bodies come about and change as entanglements between a series of inside and outside forces to their bodies. Analysing these bodies with natural-science methods such as isotope analysis could give evidence for both migratory histories and the food and waters consumed and the roads travelled, as well as how these externalities compose under the skin and merge with the body and internalize within it. That the lived environment diffracts within the body also underlines the fact that we are more than our bodies, we are bodies that are tied to and co-produced transcorporeally by a range of shadow places that we have eaten from, drunk from and travelled through - the landscape is in us and we are in it-but also these bodies project out and transform the environment. These bodies are more-than male bodies, despite being produced as such through osteological apparatuses; they are the food that has been taken in, the waters drunk, the air inhaled and the substances the body was deposited in that may have infiltrated the remains. However, they are being produced as phenomena of a sacrificial masculinity, through shifting entanglement and long processes of cause and effect, that suggests they were not only selected for deposition in bogs, but also materially-discursively made 
killable and produced through life- and deathhistories of othering. These bodily remains have not stopped their work after death, but have been active in a variety of processes, some that act out faster paces and others in slow motion as they have decayed, merged with the environment and entered new relations when resurrected as museum objects for study.

If bodies are traced as transcorporeal assemblages, this could also change how archaeologists use and contextualise DNA analysis in archaeology. For example, mitochondrial DNA could show direct maternal line and Y-chromosomes male lineage, as also these male bodies would have come about through such reproductive histories. Such results are often communicated by a family tree of genetic lineage. However, such family trees were tools that politically mobilized both imperialism and colonialism during the nineteenth century (Åsberg 2005, 245, 252-3). Furthermore, such approaches also risk producing histories that place heterosexual intercourse and reproduction at centre stage in our narratives and may work to further the academic/political focus on male and female as the only 'two kinds of citizens and their offspring - the fully human' (compare Barad 2007, 59). While such relations may have been of importance, this downplays networks of care and belonging that include relationships to other species and things. If the scientific results are used in a thought structure of genealogy, these results will describe a history and connections that have a source and origin and causality and that give rise to narratives of linear progress, for example as family, tribe or clan, and exclude other ways of encountering ancestry and family that may include a range of othered others.

Barad's apparatus provides us with more tools with which to engage with natural sciences, such as for example DNA analysis or osteology. The term agential cut is used by Barad $(2007,148)$ to point out that phenomena arise as acts of observation make cuts into an interconnected reality, and thereby separate what is considered in an analysis from what is not. With this background, DNA analysis in archaeology is one lens that allows particular phenomena to arise and be let into history writing, but such phenomena also hide other excessive relations from coming into play. If so, the scientific and theoretical apparatuses used in archaeology perform cuts that temporarily stabilize sex/gender phenomena.

Furthermore, human and animal bodies entangle with each other. This is exemplified by Harris (2020), who has recently worked with osteological and zooarchaeological arctic assemblages to highlight that gender-structured maintenance work such as infant feeding and the care of dogs is evidenced in isotope ratios and aDNA results: hence, care stretched across the human-animal binaries. The analysis of nitrogen and stable carbon isotope analysis of dog bones and fur (identified genetically) imply that they, in situated cases, shared food with humans where humans were important for the upkeep of the dogs, but where also the dogs were acting as eyes and ears for humans (Harris 2020, 173). Hence, such a case shows how human-dog relations worked to build up relations transcorporeally-across bodies-in many different ways. Isotope analysis shows that human-provided seafood made material changes in the fabric of the bodies of dogs. Furthermore, dogs carried out work prosthetically for humans as they enhanced sensory capacities for humans-humans likewise provided physical extensions of dog bodies in the catching of fish for them to feed on jointly. This evidence informs of spatially and temporally entangled human-gender-animal relations where bodies were materially-discursively woven together where both humans and dogs contributed to these ways of worlding the world.

In effect a body is a temporal assemblage that emerges and materializes through various entangled processes. But as Barad $(2007,58)$ also writes, it is not only about including the excluded. Archaeological narratives built on scientific analysis also need to figure out how such dissection is carried out, and when contending with Butler (1993) that gender is performed, this needs to be taken one step further to take on board a more dynamic appreciation of matter. In short, to acknowledge bodies as materialdiscursive entanglement makes clear that whereas words make the world, also worldly and historically formed materialities force themselves on us, so that we have to word them and bring them into history writing.

\section{What can critical feminist posthumanism do for archaeology?}

So, drawing together this reasoning, what can critical feminist posthumanism do for engagement with the archaeological sciences and for gender archaeology? These approaches (with reference to Barad 2007, 33-5) provide a game-changer for gender archaeology as they open up analysing bodies as more-than-human materializing forces - hence this allows for a focus on agentialities that cross between fields of nature and culture. Agential realism further challenges anthropocentrism and widens our vision from seeing the human as an essential category; it opens up studies into how bodies become and 
transform transcorporeally over time in relation with others. What is proposed through critical feminist posthumanism is that the discursive field is not privileged over the material, as archaeological body theories inspired by Butler may have done, or those theories that are based on an understanding of gender as a category inscribed on mute-material bodies. Instead, categories as analytical tools intra-act with material bodies and gel to produce scientifically observed phenomena. Furthermore, these new alleyways criss-crossing between the differently termed waves of feminism provide new ways of engaging with statements such as bodies are gendered down to the bones. Such approaches may need to be complemented with an acknowledgement of the variety of relations that makes gendered bodies rise as phenomena, where discursive gender performances might be one such force among others, but where a range of other matter 'matters' in the production of bodies.

Furthermore, for example Barad $(2007,66)$ offers tools for discovering how the historical and biological are bound together, how a range of material-discursive forces from the geological, organic, genetic, to the social and cultural, are of importance for situated materializing processes of bodily entanglements. Taken together, these entry points could be fruitful for the development of gender studies and archaeology; these areas, such as focusing on non-essentialist bodily connectivities and co-becomings, or exploring the relationship between dead and alive, are fields in which feminist new materialists have taken a great interest, while acknowledging earlier feminisms; such efforts could also be helpful in archaeology for throwing light on the areas left to one side by earlier studies.

This reasoning provides new entry points for how to stitch between archaeological sciences and gender archaeology. Further, through the focus on processes of intra-action, 'agential realism' works to question boundaries between binaries such as that between material and cultural in non-dualistic ways that also acknowledge the agentialities and discursivities of matter. Braidotti $(2013,96)$ writes that 'the most striking feature of the current scientific redefinition of "matter" is the dislocation of difference from binaries to rhizomatics; from sex/gender or nature/culture to processes of sexualization/racialization/naturalization that take life itself, or the vitality of matter as the main target'. As an integral part of gender archaeology, an engagement with critical feminist posthumanism brings into view that power differentials are not only aligned as binaries between men and women, but come about through the structuring of relationships with materialities, animals and the environment. Hence, science and technology studies as well as human-animal studies have the potential to renew gender studies in archaeology. The approaches showcased here call into question a range of binaries, not only the sex-gender one, but also those boundaries set up between humansnature and between life and death to recognize additional forces that play a role in bringing about historical stability and change. Here, interesting work is taking place within the emerging field of queer death studies (Radomska et al. 2019), where tools from feminist posthuman materialism and queer theory are enrolled to study processes around dying, death and mourning to unpack and question normativities around death. These are fields where interlinkages with scientifically engaged gender archaeology can be made.

Christina Fredengren
Stockholm University
Department of Archaeology and Classical Studies
Archaeological Research Laboratory
Wallenberg Laboratory
Stockholm 10691
Sweden
Email: christina.fredengren@arklab.su.se

\section{References}

Alaimo, S., 2010. Bodily Natures: Science, environment, and the material self. Bloomington (IN): Indiana University Press.

Åsberg, C., 2005. Genetiska föreställningar: Mellan genus och gener i populär/vetenskapens visuella kulturer [Genetic conceptions: between gender and genes in popular/science's visual cultures]. Linköping: Linköpings Universitet.

Barad, K., 2007. Meeting the Universe Halfway: Quantum physics and the entanglement of matter and meaning. Durham (NC): Duke University Press.

Braidotti, R., 2013. The Posthuman. Cambridge: Polity.

Butler, J., 1990. Gender Trouble: Feminism and the subversion of identity. London/New York: Routledge.

Butler, J., 1993. Bodies That Matter: On the discursive limits of 'sex'. London/New York: Routledge.

Engelstad, E., 2007. Much more than gender. Journal of Archaeological Method and Theory 14, 217-34.

Fowler, C., 2013. The Emergent Past: A relational realist archaeology of Early Bronze Age mortuary practices. Oxford: Oxford University Press.

Fredengren, C., 2013. Posthumanism, the transcorporeal and biomolecular archaeology. Current Swedish Archaeology 21, 53-71.

Fredengren, C., 2017. Unexpected encounters with deep time enchantment. World Archaeology 48(4), 482-99. 
Fredengren, C., 2018a. Archaeological posthumanities: feminist re-invention of humanities, science and material pasts, in Reinventing the Humanities, eds R. Braidotti \& C. Åsberg. New York (NY): Springer, 129-40.

Fredengren, C., 2018b. Becoming bog bodies. Sacrifice and politics of exclusion, as evidenced in the deposition of skeletal remains in wetlands near Uppåkra. Journal of Wetland Archaeology 18(1), 1-19.

González-Ruibal, A., 2018. Beyond the Anthropocene: defining the Age of Destruction. Norwegian Archaeological Review 51, 1-2, 10-21.

Harris, A., 2020. Palaeodiet and Infant Feeding in Coastal Arctic Settlements. Insights from stable isotope analysis of bone and dentine collagen and amino acids. (Theses and Papers in Scientific Archaeology 18.) Stockholm: Stockholm University.

Harris, O. \& C. Cipolla, 2017. Archaeological Theory in the New Millennium: Introducing current perspectives. London: Routledge.

Hjørungdal, T., 2012. 'Møder i Mosen' - Metodmöten i Maglemoses forskningshistoria [Meetings in the bog - methodological meetings in the research history of Maglemose], in Att àterupptäcka det glömda: Aktuell forskning om forntidens förflutna $i$ Norden [Rediscovering the forgotten: Current research on the ancient past in the North], eds P. Nicklasson \& R. Petersson. Lund: Institutionen för arkeologi och antikens historia, Lunds universitet, 325-36.

Marshall, Y. \& B. Alberti, 2014. A matter of difference: Karen Barad, ontology and archaeological bodies. Cambridge Archaeological Journal 24(1), 19-36.

Radomska, M., T. Mehrabi \& N. Lykke, 2019. Queer death studies: coming to terms with death, dying and mourning differently. An introduction. Women, Gender E Research 2, 3-11.
Sofaer, J., 2006. The Body as Material Culture: A theoretical osteoarchaeology. Cambridge: Cambridge University Press.

Sofaer, J., 2013. Bioarchaeological approaches to the gendered body, in A Companion to Gender Prehistory, ed. D. Bolger. Malden (MA): Wiley-Blackwell, 226-43.

Sørensen, M.L.S., 2013. The history of gender archaeology in northern Europe, in A Companion to Gender Prehistory, ed. D. Bolger. Malden (MA): WileyBlackwell, 396-412.

Sørensen, T.F., 2017. The two cultures and a world apart: archaeology and science at a new crossroads. Norwegian Archaeological Review 50(2), 101-15.

van der Tuin, I., 2014. Generational Feminism: New materialist introduction to a generative approach. London: Lexington Books.

Witmore, C., 2015. Archaeology and the second empiricism, in Debating Archaeological Empiricism: The ambiguity of material evidence, eds C. Hillerdal \& J. Siapkas. New York/London: Routledge, 37-61.

\section{Author biography}

Christina Fredengren is Head of Research at the National Historical Museums in Sweden and Associate Professor at Stockholm University. She has an interest in how the archaeological sciences meet with gender theories of new materialism, critical posthumanism and the more-than-human humanities. Furthermore, her research works at the intersection of heritage studies and the emerging field of environmental humanities, with a particular interest in humananimal relations, queer death studies and deep time. 